Original Article

\title{
Pinworm infection in school children of four districts of Malakand region, Khyber Pakhtunkhwa, Pakistan
}

\author{
Infecção por Pinworm em crianças em idade escolar de quatro distritos da região de \\ Malakand, Khyber Pakhtunkhwa, Paquistão
}

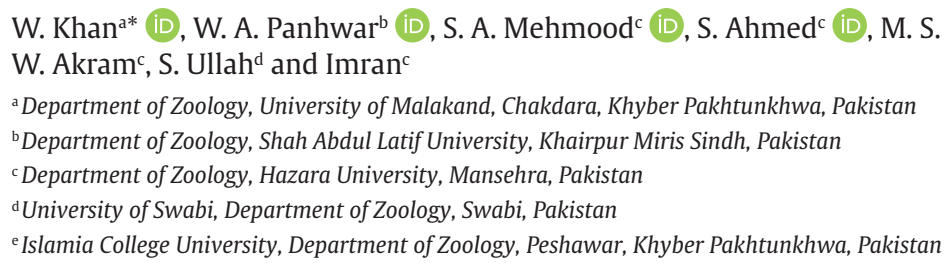

\begin{abstract}
Illnesses caused by human pinworm remains a pediatric health problem in developing nations including Pakistan. This study aimed to investigate the prevalence of Enterobius vermicularis in school children of four districts in Malakand region, Pakistan. Four hundred faecal specimens were screened from May 2014 to July 2017 using normal saline and Lugol Iodine solution. Twenty three (5.75\%) individuals were found infected with E. vermicularis. Five children (1.25\%) were infected with only E. vermicularis and eighteen (4.5\%) were mixed with other helminths. E. vermicularis 23 (5.75\%), hookworm 11 (2.75\%), Ascaris lumbricoides 5 (1.25\%), Taenia saginata $2(0.5 \%)$ and Trichuris trichuira 4 (1\%) were detected. Age wise 5-8 years were more parasitized followed by $13-15$ and $9-12$ years of age $(0.0296, \mathrm{P}<0.05)$. Male children were highly $(0.06700, \mathrm{P}<0.05)$ infected than female. Children in Malakand district were found more infected followed by Dir Upper, similar infection rate was noted in children of districts Lower Dir and Swat $(0.0192, \mathrm{P}<0.05)$. Children in primary level were highly $(0.0013, \mathrm{P}<0.05)$ infected than those of middle and high levels. Enterobiosis is still the most common parasitic diseases in children. Studies on enterobiosis should be conducted time by time to recognize the hazardous of such parasitic infection in remote areas of the country.
\end{abstract}

Keywords: enterobiosis, oxyuriasis, human pinworms, child health, intestinal nematode.

\begin{abstract}
Resumo
As doenças causadas pela traça humana continuam sendo um problema de saúde pediátrica nos países em desenvolvimento, incluindo o Paquistão. Este estudo teve como objetivo investigar a prevalência de Enterobius vermicularis em escolares de quatro distritos na região de Malakand, Paquistão. Quatrocentos espécimes fecais foram selecionados de maio de 2014 a julho de 2017, usando solução salina normal e solução de lugol iodo. Vinte e três $(5,75 \%)$ indivíduos foram encontrados infectados por E. vermicularis. Cinco crianças (1,25\%) foram infectadas apenas com E. vermicularis e dezoito (4,5\%) foram misturadas com outros helmintos. Foram detectados E. vermicularis 23 (5,75\%), ancilóstomo 11 (2,75\%), Ascaris lumbricoides 5 (1,25\%), Taenia saginata $2(0,5 \%)$ e Trichuris trichuira 4 (1\%). Com relação à idade, 5-8 anos foram mais parasitados, seguidos por 13-15 e 9-12 anos de idade $(0,0296, \mathrm{P}<0,05)$. Crianças do sexo masculino foram altamente $(0,06700, \mathrm{P}<0,05)$ infectadas do que as do sexo feminino. As crianças no distrito de Malakand foram encontradas mais infectadas, seguidas por Dir Upper, taxa de infecção semelhante foi observada em crianças dos distritos Lower Dir e Swat $(0,0192, \mathrm{P}<0,05)$. As crianças do nível primário foram altamente $(0,0013, \mathrm{P}<0,05)$ infectadas do que as dos níveis médio e alto. A enterobiose ainda é a doença parasitária mais comum em crianças. Os estudos sobre enterobiose devem ser conduzidos periodicamente para reconhecer a periculosidade dessa infecção parasitária em áreas remotas do país.
\end{abstract}

Palavras-chave: enterobiose, oxiuríase, oxiúros humanos, saúde infantil, nematóide intestinal.

*e-mail: walikhan.pk@gmail.com

Received: May 28, 2020 - Accepted: July 23, 2020

This is an Open Access article distributed under the terms of the Creative Commons Attribution License, which permits unrestricted use, distribution, and reproduction in any medium, provided the original work is properly cited. 


\section{Introduction}

Enterobiosis has a wide range of geographic distribution and is prevalent in developing and even in developed nations. Intestinal enterobiosis affects more than 400 million people throughout the world. It rarely affects tropical people because its eggs cannot survive in hot dry conditions for long time (Afrakhteh et al., 2016). Though most parasitic infections have been eradicated in developed nations, E. vermicularis infection is still often reported in many developed nations. In Pakistan the prevalence of enterobiosis has sharply increased from $0.2 \%$ in 1964 to $14.1 \%$ in 2017 (Farooqi, 1964; Khan et al., 2017a).

Enterobiosis is acquired by eating of eggs having the $3^{\text {rd }}$ stage larvae and infection is often directly transmitted from anus to mouth via hands, water or food contaminated by the eggs. Larvae emerges from the ingested eggs in the duodenum and travel to the caecum to become sexually mature (Freedman et al., 1994). Males die after copulation, while egg-bearing females travel to the perianal and perineal regions, where they lay up to 11,000 eggs. The female usually return to the colon or die after laying eggs (Bogitsh et al., 2013). Eggs may also be deposited on clothing and bed linen, and are subsequently either ingested or inhaled (Park et al., 2005).

Enterobiosis is often described as a childhood infection caused by E. vermicularis (human pinworm), also known as oxyuriasis (Roberts and Janovy Junior, 2009). Enterobius vermicularis is the pinworm of the large intestine of man, which causes perianal itching and irritability, abdominal discomfort, loss of appetite, weight loss, insomnia, restlessness, enuresis (Kubiak et al., 2017), recurrent urinary tract infections (Choudhury et al., 2017) and appendicitis (Ahmed et al., 2015). Occasionally, pinworms penetrate into the submucosa resulting to a fatal diseases. They may also, penetrate extraintestinal sites like vulva, vagina, uterus, fallopian tubes, ovary, peritoneum, lung, liver, breast, spleen ( $\mathrm{Ng}$ et al., 2011), male urinary tract (Zahariou et al., 2007) nose (Kaniyur et al., 2005) and conjunctival sacs (Dutta and Kalita, 1976) and leads to ectopian enterobiosis.

Studies from different parts of Pakistan in the last two decades report prevalence rates of enterobiosis, as $13.8 \%$ Jamil (1999); 2.61\% Shaikh et al. (2003); 1.3\% Chaudhry et al. (2004); 16.3\% Maqbool et al. (2007); 1.8\% Sajjad et al. (2009); 10.3\% (Nisa et al., 2011); 12\% (Khan et al., 2012); 8\% (Khan et al., 2015); 9.73\% (Khan et al., 2017a) and 9.52\% (Khan et al., 2018a) and 6.48 (Khan et al., 2018b). Recently, most studies have focused on intestinal parasitic infections among the human population of Pakistan with little on the prevalence of human pinworm infection. This paper presents observation on the prevalence of pinworm infection among school children in four districts of Malakand region, Pakistan.

\section{Materials and Methods}

\subsection{Study area}

A cross-sectional study was conducted in Malakand Division (the northwest of Pakistan) which covers nearly
$40 \%$ of the area of Khyber Pakhtunkhwa province Pakistan. It covers an area of nearly $29,800 \mathrm{~km}^{2}$ and has a population of about 6.0 million people. Malakand Division is situated between latitudes of $35^{\circ} 29^{\prime} 59.99^{\prime \prime}$ North and longitudes of $72^{\circ} 00^{\prime} 0.00$ " East with $1420 \mathrm{~m}$ in elevation. Of the 7 districts in Malakand division four namely Malakand, Lower Dir, Upper Dir and Swat were selected for the current study. These districts were selected due to the reasons that most of the studies on human intestinal parasitic infections were conducted previously.

\subsection{Data collection}

The study was conducted from May 2014 to July 2017. A total of 400 stool samples from children (324 boys and 76 girls) of 5 to 15 years of age attending government schools, were collected. Prior to initiation of the study, a structured questionnaire to collect demographic data (age, sex, date of collection, locality, intestinal complaints, and previous anti- parasitic therapy) was developed. A meeting was held with school authorities and guardians of the children to discuss the purpose of the study and to take permission to carry out the study. A day before specimen collection, all the children (participants) were given verbal instructions on handling and collection of fecal samples with provided clean, dry, screw capped, widemouth plastic bottles containing 10\% M.I.F (Merthiolate, Iodine, Formaldehyde) preservatives and wooden spatula. The children were instructed to collect about 10 grams of feces. All the samples were then brought to the Laboratory of Parasitology, Zoology Department, University Of Malakand for further processing. We excluded from the study, children who were either treated with anti-helminths or were allowed by parents to participate in the study.

\subsection{Microscopic examination}

The laboratory investigation was carried out through Wet Mount Techniques, of normal saline and Lugol, iodine solution. Sedimentation, floatation and centrifugation procedures and techniques, were also used for confirmation of the results.

\subsection{Statistical analysis}

Data were analyzed descriptively using Graph Pad version 5. Probability values less than or equal to 0.05 were considered significant $(\mathrm{P} \leq 0.05)$.

\section{Results}

The overall prevalence of $E$. vermicularis among school children was $5.75 \%$ (23/400) with boys $6.48 \%(21 / 324)$ showing more prevalence than girls $2.63 \%$ (2/76) $(0.6700, \mathrm{P}>0.05)$. Children aged $5-8$ years showed the highest prevalence $(8.18 \% ; 9 / 110)$ compared to other age groups $(0.0296, \mathrm{P}<0.05)$. Children in Malakand district were found more infected followed by those in Dir Upper. Similar infection rate was noted in children of districts Lower Dir and Swat $(0.0192, \mathrm{P}<0.05)$. Children in primary 
level were highly infected than those of middle and high level $(0.0013, \mathrm{P}<0.05)$ (Table 1$)$.

Most positive children had multiple gastrointestinal helminth infections (double and triple) rather than single infections. The total number of single, double and triple infected cases were 5, 14 and 4 respectively, making $1.25 \%, 3.5 \%$ and $1 \%$ of the total examined individuals and $21.73 \%, 60.86 \%$ and $17.39 \%$ of the total infected persons, respectively. It was found that in double parasitic infection, E.cvermicularis was more likely to associate with hookworm, followed by $T$. saginata and A. lumbricoides. Double infections were higher in Malakand District as compared to others. In Lower Dir, association was with hookworm only. In Malakand, association was with hookworm and T. saginatta. In Upper Dir, there was no double association while in Swat, double association was with A.lumbricoides (Table 2).

Table 3 indicates the parasites which are in association with E. vermicularis in the current study. Total number of infections was reported as $11.2 \%(n=45)$ including

Table 1. Prevalence of E. vermicularis by sex and age among school children in Malakand region, Pakistan.

\begin{tabular}{|c|c|c|c|c|c|c|c|}
\hline \multirow{2}{*}{ categories } & \multicolumn{6}{|c|}{ No. of children positive/ No. of children examined (\%) } & \multirow{2}{*}{ P value } \\
\hline & Dir lower & Dir upper & Swat & Malakand & Total & Prevalence & \\
\hline \multicolumn{8}{|l|}{ Age } \\
\hline $5-8$ & $0 / 35$ & $2 / 32$ & $2 / 33$ & $5 / 10$ & 9/110 & $8.18 \%$ & \multirow{4}{*}{0.0296} \\
\hline $9-12$ & $1 / 28$ & $4 / 48$ & $0 / 35$ & $2 / 47$ & $7 / 158$ & $4.43 \%$ & \\
\hline \multirow[t]{2}{*}{$13-15$} & $1 / 37$ & $2 / 20$ & $0 / 32$ & $4 / 43$ & $7 / 132$ & \multirow[t]{2}{*}{$5.30 \%$} & \\
\hline & $2 / 100(2 \%)$ & $8 / 100(8 \%)$ & $2 / 100(2 \%)$ & $11 / 100(11 \%)$ & $23 / 400$ & & \\
\hline \multicolumn{8}{|l|}{ Sex } \\
\hline Male & $2 / 81$ & $6 / 73$ & $2 / 85$ & $11 / 85$ & $21 / 324$ & $6.48 \%$ & \multirow{3}{*}{0.6700} \\
\hline \multirow[t]{2}{*}{ female } & $0 / 19$ & $2 / 27$ & $0 / 15$ & $0 / 15$ & $2 / 76$ & $2.63 \%$ & \\
\hline & $2 / 100$ & $8 / 100$ & $2 / 100$ & $11 / 100$ & $23 / 400$ & $5.75 \%$ & \\
\hline
\end{tabular}

Table 2. Prevalence and pattern of single and mixed intestinal parasitic helminth infections in relation to E. vermicularis among school children in Malakand region, Pakistan.

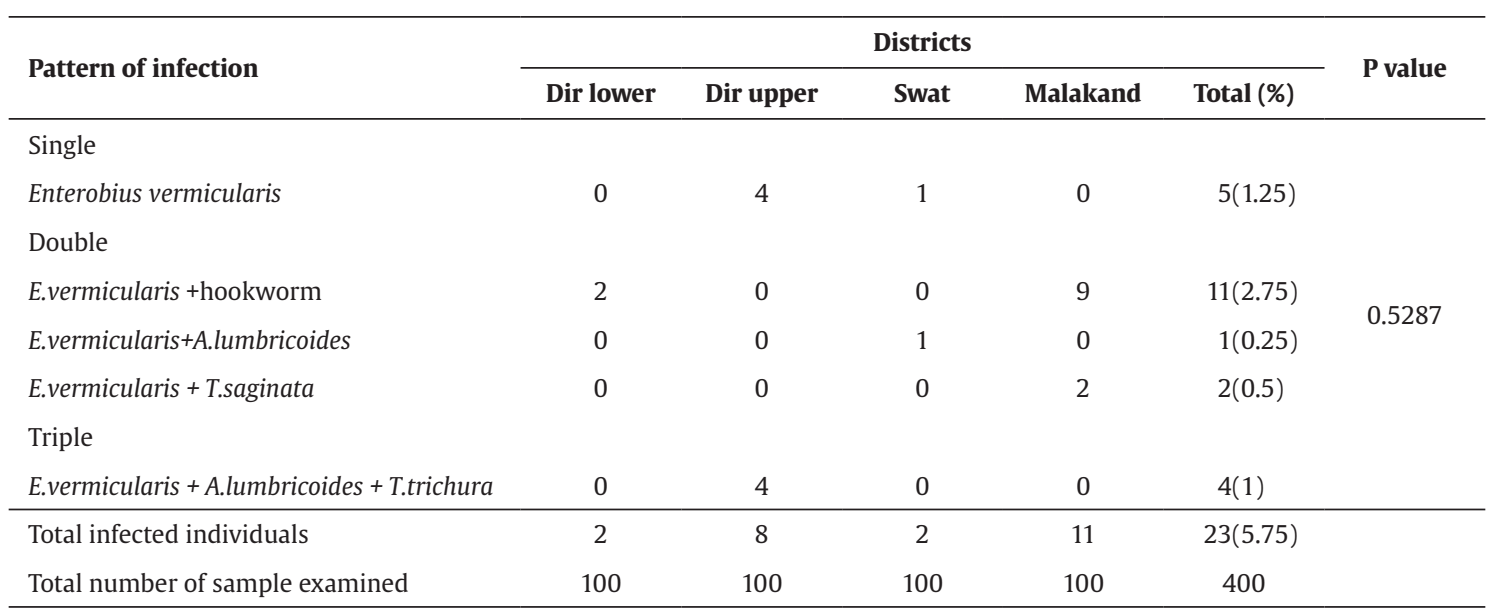

Table 3. Prevalence of E. vermicularis in combination with other helminth infections among school children in Malakand region, Pakistan.

\begin{tabular}{lcc}
\hline \multicolumn{1}{c}{ Parasite } & Number infected & Prevalence (\%) \\
\hline Enterobius vermicularis & 23 & $5.75 \%$ \\
Hook worm & 11 & $2.75 \%$ \\
Ascaris lumbricoides & 5 & $1.25 \%$ \\
Taenia saginata & 2 & $0.5 \%$ \\
Trichuris trichura & 4 & $1 \%$ \\
Total No. of infection & 45 & $11.25 \%$ \\
\hline
\end{tabular}


5.75\% ( $\mathrm{n}=23)$ E. vermicularis, 2.75\% $(\mathrm{n}=11)$ hookworm, $1.25 \%(\mathrm{n}=5)$ A. lumbricoides, $0.5 \%(\mathrm{n}=2)$ T. saginata and $1 \%(\mathrm{n}=4)$ T. trichura.

\section{Discussion}

In Pakistan the prevalence of human pinworm ranges from 2\% (Farooqi, 1964) to 16.3\% (Maqbool et al., 2007). This nematode remains as the most important intestinal pathogenic parasite specifically in children. The transmission of this pinworm occurs via ingestion of infectious eggs by direct anus-to-mouth transfer by fingers. This is facilitated by the perianal itch (pruritis ani) induced by the presence of pinworm eggs in the perianal folds, and commonly occurs as a result of nail biting, poor hygiene, or inadequate hand-washing.

We determined the prevalence of pinworm infection among school children of 5 to 15 years age in four districts of Malakand Division, Pakistan. In the current study, prevalence of $E$. vermicularis is $5.75 \%$, which is comparable to Bilqees et al. (1982) in mixed population of Karachi. Siddiqi and Bano (1979) described 3.5\% of the infection in school children of Peshawar district. According to the study conducted by Pal and Subhani (1989), 3.03\% of the infection rate was reported in school children of Dir, district. Findings of the current study was comparatively low, when compared to the study conducted by Maqbool et al. (2007), who reported $16.3 \%$ of the infection in urban and rural population of Lahore. Jamil (1999) also reported high infection rate (13.8\%) in urban and suburban areas of Islamabad . Khan et al., 2012 reported 12\% prevalence. Pal and Malik (1979) noted 9.1\% prevalence rate in school children of Islamabad. A high prevalence of $8 \%$ was noted by Khan et al., 2015 in education sectors of Swat, Pakistan. Khan et al. (2017b) reported $9.73 \%$ prevalence among food handlers of Swat Pakistan . The highest prevalence rate (14.1\%) of pinworm was reported in different occupational groups of district Swat, Pakistan (Khan et al., 2017a).

District wise, prevalence rates were $11,8,2$, and $2 \%$ in Malakand, Dir Upper, Swat and Dir lower respectively. Malakand was found to be more affected than others. In the present study, Swat showed decrease in prevalence as compared to previous study (7.56\%) reported by Khan et al (2012). reported $1.35 \%$ infection rate in Dir Upper which increased in our study to $8 \%$.

Higher infection rate in boys (6.48\%) was observed than in girls $(2.63 \%)$. This is in accordance with Park et al (2005), Hazratitappeh et al (2002) and Requena et al (2007). However, some studies like Afrakhteh et al. (2016), Amiri et al. (2016), Li et al (2015), Suraweera et al. (2017), Chai et al. (2015), Nourozian and Youssefi (2013), Haghi et al. (2013), and Chang et al. (2009) reported no significant association between prevalence of pinworm infection and sex of infected individuals.

According to Afrakhteh et al. (2016), Nithikathkul et al. (2001) and Bunchu et al. (2011) there is association between prevalence of Enterobius vermicularis infection with age of the host. Amiri et al (2016), Suraweera et al. (2017) and Park et al. (2005), reported no significant difference between age while Li et al. (2015) reported significant difference between age and infection prevalence. In the present study, most infected children were $5-8$ years in age which is consistent with many other studies such as Taylor et al. (2018) and Nithikathkul et al. (2001). In present study also, we found that E.vermicularis was likely to occur in co-infection with other intestinal parasites like hookworm, A. lumricoides, T. saginatta and T. trichura. These association were also reported by Khan et al. (2012).

E.vermicularis is also present in variable rate of prevalence in human population of Pakistan as: 0.6\%, 0.2\% and 0.2\% Farooqi (1964); 0.5\%; 1.5\% Baqai and Zuberi (1986); 2.3\% Ali (1993); 2.61\% Shaikh et al. (2003); $1.3 \%$ Chaudhry et al. (2004); 1.8\% Sajjad et al., (2009). Variations in prevalence of pinworm in the different parts, might be due to the variable climatic conditions, personal habits, cultural and geographical limitations.

\section{Conclusions}

The current study offers new vision on prevalence of pinworm infection among school children in four districts of Malakand region, Pakistan. This research findings highlight the need for children health and rural communities' improvement in the remote parts of Pakistan. Intervention of health awareness programs should be compulsory to minimize spread and reinfection of such infections in the population.

\section{References}

AFRAKHTEH, N., MARHABA, Z., MAHDAVI, S.A., GAROOSIAN, S., MIRNEZHAD, R., VAKILI, M.E., SHAHRAJ, H.A.,JAVADIAN, B., REZAEI, R. and MOOSAZADEH, M., 2016. Prevalence of Enterobius vermicularis amongst kindergartens and preschool children in Mazandaran Province, North of Iran. Journal of Parasitic Diseases : Official Organ of the Indian Society for Parasitology, vol. 40, no. 4, pp. 1332-1336. http://dx.doi.org/10.1007/s12639-015-0683-z. PMid:27876942.

AHMED, M.U., BILAL, M., ANIS, K., KHAN, A.M., FATIMA, K., AHMED, I., KHATRI, A.M. and REHMAN, S.U., 2015. The frequency of Enterobius vermicularis infections in patients diagnosed with acute appendicitis in Pakistan. Global Journal of Health Science, vol. 7, no. 5, pp. 196-201. http://dx.doi.org/10.5539/ gjhs.v7n5p196. PMid:26156929.

ALI, N., 1993. A survey of intestinal helminthes of man in Kurram agency. Islama abad, Pakistan: Department of Biological Sciences, Quad-i-Azam University, 1.75p M.Phil Thesis.

AMIRI, S.A.N., RAHIMI, M.T., MAHDAVI, S.A., MOOSAZADEH, M., RAMZANI, O., KOSHK, A.F., ROSBEHAN, R. and SIYADATPANAH, S.A., 2016. Prevalence of Enterobius vermicularis infection among preschool children, Babol, North of Iran. Journal of Parasitic Diseases, vol. 40, no. 4, pp. 1558-1562. http://dx.doi. org/10.1007/s12639-015-0727-4.

BAQAI, R. and ZUBERI, S.J., 1986. Prevalence of intestinal parasites in diarrhoeal patients. JPMA. The Journal of the Pakistan Medical Association, vol. 36, no. 1, pp. 7-11. PMid:3084818.

BILQEES, F.M., KHAN, A. and AHMAD, A., 1982. A survey of intestinal protozoan and helminth parasites in Karachi. Pakistan Journal of Medical Research, vol. 21, pp. 54-57.

BOGITSH, B.J., CARTER, C.E. and OELTMANN, T.N., 2013. Human parasitology. Netherland: Netherland publisher, pp.321- 322 
BUNCHU, N., VITTA, A., THONGWAT, D., LAMLERTTHON, S., PIMOLSRI, U., WAREE, P., WONGWIGKARN, J., KHAMSRI, B., CHEEWAPAT, R. and WICHAI, S., 2011. Enterobius vermicularis infection among children in lower northern Thailand. J Trop Med Parasitol., vol. 34, pp. 36-40.

CHAI, J., YANG, S.E., KIM, J.W., CHOI, S.L., SONG, G., JUNG, B., KIM, M., CHO, J., KIM, D., SOHN, W., JEOUNG, H., CHO, S., PARK, J., HONG, S., HTOON, T.T. and TIN, H.H., 2015. High prevalence of Enterobius vermicularis Infection among Schoolchildren in Three Townships around Yangon, Myanmar. The Korean Journal of Parasitology, vol. 53, no. 6, pp. 771-775. http://dx.doi. org/10.3347/kjp.2015.53.6.771. PMid:26797448.

CHANG, T., LIAO, C., HUANG, Y., CHANG, C., CHOU, C., TSAY, H., HUANG, A., GUU, S., KAO, T.C. and FAN, C.K., 2009. Prevalence of Enterobius vermicularis Infection among preschool Children in Kindergartens of Taipei City, Taiwan in 2008. Korean Journal of Parasitology, vol. 47, no. 2, pp. 185-187. http://dx.doi.org/10.3347/ kjp.2009.47.2.185. PMid:19488428.

CHAUDHRY, Z.H., AFZAL, M. and MALIK, M.A., 2004. Epidemiological factors affecting Prevalence of of intestinal parasites in children of Muzaffarabad district. Pakistan Journal ofZoology, vol.36, pp. 267-271.

CHOUDHURY, S., KUMAR, B. and PAL, D.K., 2017. Enterobius vermicularis infestation of urinary tract leading to recurrent urinary tract infection. Tropical Parasitology, vol. 7, no. 2, pp. 119-121. http://dx.doi.org/10.4103/tp.TP-22-17. PMid:29114492.

DUTTA, L.P. and KALITA, M., 1976. Enterobius vermicularis infestation of the appendix and management at the time of laparoscopic appendicectomy: case series and literature review. International Journal of Surgery, vol. 8, no. 6, pp. 466-469.

FAROOQI, M.A., 1964. An investigation of human intestinal parasitism in some areas of Pakistan. Pakistan Journal of Medical Research, vol. 3, pp. 113-115.

FREEDMAN, D.O., KLASS, J. and HOWARD, B.J., 1994. Clinical and pathogenic microbiology. St. Louis, Washington DC, Toronto: The C.V. Mosby Company, pp. 663-665.

HAGHI, S.M., NAJM, M., FAKHAR, M., GHOLAMI, S. and HAGHI, S.F.M., 2013. Prevalence of Enterobius vermicularis infection among kindergartens in Mazandaran Province, 2011. Journal of Mazandaran University of Medical Sciences, vol. 23, pp. 241-247.

HAZRATITAPPEH, K.H., SALARI, S.H., ALMASI, R. and MOHAMMAD, Z.H., 2002. Prevalence of Oxyuris in Kindergartens in Urmia and disease control methods. Journal of Kurdistan University of Medical Sciences, vol. 7, pp. 34-29.

JAMIL, F., 1999. An analysis for the prevalence of human intestinal helminth parasites in urban and suburban communities of Islamabad. Islamabad, Lahore, Pakistan: Department of Biological Sciences, Quaidi-Azam University, pp. 1-98 M. Phil. thesis.

KANIYUR, V., PRASAD, K.H.C., DEVAN, P.P., DODDAMANI, S.S., BALACHANDRAN, B. and KULKARNI, V., 2005. Enterobius vermicularis in the nose: a rare entity. Indian Journal of Otolaryngology and Head and Neck Surgery, vol. 57, no. 2, pp. 148-150. PMid:23120157.

KHAN, W., UN-NISA, N. and KHAN, A., 2018A. Prevalence of Potentially Important Intestinal Pathogenic Protozoan Parasitic Infections in Different Occupational Groups of Swat, Pakistan. Pakistan Journal of Zoology, vol. 50, no. 1, pp. 123-129. http:// dx.doi.org/10.17582/journal.pjz/2018.50.1.123.129.

KHAN, W., NISA, N.-U. and NAWAZ, M.A., 2018b. Incidence of tapeworm infection in human population of Swat, Pakistan: an occupation based study. Pakistan Journal of Zoology, vol 50, no. 2, pp. 639-639. http://dx.doi.org/10.17582/journal. pjz/2018.50.2.639.645.
KHAN, W., MUMTAZ, G., BIBI, S. and AFZAL, S., 2017b. Parasitic contamination of fresh vegetables sold at Upper and Lower Dir districts, Khyber Pakhtunkhwa, Pakistan. Pakistan Journal of Zoology, vol. 49, pp. 1115-1118. http://dx.doi.org/10.17582/ journal.pjz/2017.49.3.sc3.

KHAN, W., NISA, N. and KHAN, A., 2015. Diversity of intestinal parasites in male and female students and workers of education department of Swat, Pakistan. Pakistan Journal of Zoology, vol. 47, pp. 565-568.

KHAN, W., NISA, N. and KHAN, A., 2017a. Prevalence and risk factors associated with intestinal parasitic infections among food handlers of Swat, Khyber Pakhtunkhwa, Pakistan. Journal of Food and Nutrition Research, vol. 5, no. 5, pp. 331-336. http:// dx.doi.org/10.12691/jfnr-5-5-7.

KHAN, W., NISA, N.U., KHAN, A. and NAQVI, M.H., 2012. Endemicity of intestinal parasites with special reference to nematodes in individuals related to education (students, staff and workers) in swat, kp, Pakistan. Pakistan Journal of Nematology, vol. 30, no. 1, pp. 77-85.

KUBIAK, K., DZIKA, E. and PAUKSZTO, L., 2017. Enterobiasis epidemiology and molecular characterization of Enterobius vermicularis in healthy children in north-eastern Poland. Helminthologia, vol. 54, no. 4, pp. 284-291. http://dx.doi. org/10.1515/helm-2017-0042.

LI, H.M., ZHOU, C., LI, Z., DENG, Z., RUAN, C., ZHANG, Q., ZHU, T., XU, L.Q. and CHEN, Y.D., 2015. Risk factors for Enterobius vermicularis infection in children in Gaozhou, Guangdong, China. Infectious Diseases of Poverty, vol. 4, no. 1, pp. 28. http://dx.doi.org/10.1186/ s40249-015-0058-9. PMid:26038691.

MAQBOOL, A., ALI, S.A., TANVEER, A. and MASOOD, S., 2007. Prevalence and control of food born parasitic zoonosis in Pakistan. Malaysian Applied Biology, vol. 36, pp. 1521.

NG, Y.W., NG, S.B. and LOW, J.H., 2011. Enterobius vermicularis infestation of the endometrium - a cause of menstrual irregularity and review of literature. Annals of the Academy of Medicine, Singapore, vol. 40, no. 11, pp. 514-515. PMid:22206070.

NISA, N., KHAN, W., and KHAN, A., 2011. Prevalence of intestinal parasites in male and female shepherds of Swat, Pakistan. International Journal of Biology and Biotechnology, vol. 8, no. 4, pp. 597-603.

NITHIKATHKUL, C., CHANGSAP, B., WANNAPINYOSHEEP, S., POISTER, C. and BOONTAN, P., 2001. The prevalence of Enterobius vermicularis among primary school students in Samut Prakan Province, Thailand. The Southeast Asian Journal of Tropical Medicine and Public Health, vol. 32, suppl. 2, pp. 133-137. PMid:12041577.

NOUROZIAN, M.B. and YOUSSEFI, M.R., 2013. Investigation of oxyuris (Enterobius vermicularis) prevalence in kindergarten and primary school children of Babol city, Mazandaran, Iran 2009. Annals of Tropical Medicine and Public Health, vol. 6, no. 1, pp. 20. http://dx.doi.org/10.4103/1755-6783.115171.

PAL, R.A. and MALIK, Z., 1979. Prevalence of intestinal parasites in primary school children of Islamabad. Pakistan Journal of Zoology, vol. 11, pp. 105-108.

PAL, R.A. and SUBHANI, F., 1989. Prevalence of intestinal helminth parasites in primary school children of Dir District (NWFP). Pakistan Journal of Science and Technology, vol. 13, pp. 99-102.

PARK, J.H., HAN, E.T., KIM, W.H., SHIN, E.H., GUK, S.M., KIM, J.L. and CHAI, J.Y., 2005. A survey of Enterobius vermicularis infection among children on western and Southern Coastal Islands of the Republic of Korea. The Korean Journal of Parasitology, vol. 43, no. 4, pp. 129-134. http://dx.doi.org/10.3347/kjp.2005.43.4.129. PMid: 16340301. 
REQUENA, I., JIMÉNEZ, Y., RODRÍGUEZ, N., SANDOVAL, M., ALCALÁ, F., BLANCO, Y. and DEVERA, R., 2007. Enterobius vermicularis in preschool children from a suburban area in San Felix, Bolívar State, Venezuela. Investigacion Clinica, vol. 48, no. 3, pp. 277286. PMid: 17853787.

ROBERTS, L.S. and JANOVY JUNIOR, J., 2009. Nematodes: Ascaridida, intestinal large roundworms. In: D. GERALD. Schmidt E Larry S. Roberts' Foundations of Parasitology. 8th ed. New York, NY: McGraw-Hill, pp. 431-435.

SAJJAD, N., NAWAZ, Y., NAWAZ, J. and NAWAZ, M., 2009. Gastrointestinal tract parasites study among disable Centers in Quetta City, Pakistan. Proceedings of Parasitology, vol. 47, pp. 53-59.

SHAIKH, G.S., SHAIKH, R.S. and SHAIKH, A.H., 2003. Intestinal parasitic infections in the Population of Shikarpur, Sindh. Proceedings of Parasitology, vol. 36, pp. 59-67.

SIDDIQI, M.N. and BANO, L., 1979. Observations on parasitic infections in school children of Peshawar. Pakistan Journal of Zoology, vol. 11, pp. 109-113.
SURAWEERA, O.S., GALGAMUWA, L.S., IDDAWELA, D. and WICKRAMASINGHE, S., 2017. Prevalence and associated factors of Enterobius vermicularis infection in children from a poor urban community in Sri Lanka: a cross-sectional study. International Journal of Research in Medical Sciences, vol. 3, no. 8, pp. 1994-1999.

TAYLOR, A., SAICHUA, P., RHONGBUTSRI, P., TIENGTIP, R., KITVATANACHAI, S., WALTER, R.J. and TAYLOR, W.R.J., 2018. A preliminary epidemiological study of pinworm infection in Thaklong Municipal Early Childhood Development Center and Rangsit Babies' Home, Pathum Thani, Thailand. BMC Research Notes, vol. 11, pp. 603. https://doi.org/10.1186/ s13104-018-3708-8.

ZAHARIOU, A., KARAMOUTI, M. and PAPAIOANNOU, P., 2007. Enterobius vermicularis in the male urinary tract: a case report. Journal of Medical Case Reports, vol. 1, no. 1, pp. 137. http://dx.doi.org/10.1186/1752-1947-1-137. PMid:18001478. 